\title{
THE ROLE OF HUMAN RESOURCE MANAGEMENT IN PROFESSIONAL DEVELOPMENT AND PROMOTION OF WOMEN IN ORGANIZATIONS
}

\author{
Marijana MIŠIĆ \\ Association of Centers for Interdisciplinary and Multidisciplinary Studies and Research - ACIMSI, University of Novi \\ Sad, Trg Dositeja Obradovića 5, 21000 Novi Sad, Republic of Serbia. E-mail: mima.misic@ gmail.com
}

Accepted 27 November, 2012

\begin{abstract}
In the past decades development of information technologies, increased international competition on the free market, globalization and businesses expanding outside of their countries of origin have lead to significant changes in the societies all over the world. All these changes and the world economic and social crisis have to be changed in the demographical structure of the work force, raising the issue of engaging human resources, especially women, into social and economic development. Responding to these changes and aiming to create a high level of competence, organizations today face the challenge of incorporating diversity management. Human resource management, through its policies and procedures based on diversity management, can recruit, motivate, develop and retain talented employees for all social groups, especially women. The aim of this paper is to present and analyze how policies and procedure developed by the human resources management influence professional development and promotion of women in organizations. The paper will especially analyze four types of policies and procedures: equal opportunities, development possibilities, formalizing the human resources management system and work-life balance and their influence on professional development of women in organizations. At the end, the paper will present potential avenues of further research in this field.
\end{abstract}

Key words: women, human resources management, human resources management practices, diversity.

\section{INTRODUCTION}

In the past decades many countries have faced challenges of globalisation, development of information technology and dynamic business environment. These changes together with the global financial and social crisis have brought about a change of demographical structure in the work force, raising the issue of engaging the human capital, especially women, in the social and economical development. The strength of successful and sustainable organisations is based on human capital and participation of all, women and men. Diversity management concept was the main topic of a publication titled "Work Force 2000: Work and Workers for the Twenty-First Century", indicating that organisations willing to maintain their competitiveness should change their policies and procedures in human resources management (HRM) in relation to demographically diverse work force (Johnston, 1987). HRM through its policies and procedures based on diversity management can recruit, motivate, develop and retain talented employees from all social groups, especially women.
The aim of this paper is to present and analyse how different HRM policies and procedures applied in organisations influence professional development and promotion of women in organisations. The paper will especially analyse four types of policies and procedures and their influence on professional development of women in organisations: equal opportunities, carrier development opportunities, formalisation of HRM system and work - private life balance. At the end, the paper will present the path for further research.

The most important policies and procedures of HRM in any organisation relate to: recruitment, selection, training and development, carrier development and employee retention (Fine, 1995; Heneman et al., 1996). In the context of diversity management all these HRM activities can focus on women as employees but also on other social groups.

In the process of recruitment, organizations can undertake different activities to identify and attract women and members of other social groups. In this 
context, organisations can advertise in publications aimed at women, participate in job fairs or hire recruitment agencies specialised in seeking highly qualified women and/or other social groups (Fine, 1995; Equal Opportunities Commission, 2004). Organisations can create an attractive environment for women as future employees with diverse recruitment teams, brochures, web sites and other promotional material developed on diversity management concept (Perkins et al., 2000).

In the process of selection of candidate organisations can explore if women are generally employed in certain positions more than persons from other social groups. If that turns to be the case, organisations can analyse the reasons and develop strategies to improve diversity in the selection process (Fine, 1995; Equal Opportunities Commission, 2004). In addition, organisations can create recruitment teams with members from different social groups, improving the understanding how candidates react to a divers working environment. Structured interviews can also improve the diversity concept, using identical sample of questions on all candidates help future employees to demonstrate their abilities and skills.

Training and human resources development are important segments of HRM as they can include historically excluded social groups and especially women in different training and development programs. One of the programs is leaderships skills training as an important step in career development of employees with leadership potential, leading further to development of top management based on diversity principles (Fine, 1995; Konrad and Linnehan, 1995). In addition, leadership skills training program developed specifically for women can help them develop their leadership abilities and skills, leading to leadership positions in organisations (Vinnicombe and Singh, 2003).

In the process of career development organisations should ensure that all employees, from all social groups, are included in the career development process (Fine, 1995; Konrad and Linnehan, 1995). In addition, managers in the organisation can organise individual meetings with employees to develop individual career development plans (Davidson Perlmutter et al., 2005).

In employee retention it is important for every organisation to treat all employees equally and fair (Konrad and Decktop, 2001). Organisations should provide equal access to training and career promotion to all employees from all social groups.
From diversity management aspect, organisations can research if women or persons from other social groups are leaving the organisations more than others. Based on exit interviews with employees the organisations can learn from the reasons and develop strategies to retain employees in the future (Fine, 1995; Konrad and Linnehan, 1995).

\section{THE ROLE OF POLICIES AND PROCEDURES IN HUMAN RESOURCES MANAGEMENT ON PROFESSIONAL DEVELOPMENT OF WOMEN}

Based on a large number of researches we can specify four types of HRM policies and procedures relating to professional development of women and generally other social groups: 1) equal opportunities; 2) career development; 3) formalisation of HRM system; and 4) work - private life balance.

\section{Equal opportunities}

Numerous researchers looked into whether government equal opportunity programs have positive effect on professional development of women (Leck et al., 1995; French, 2001; Leck, 2002). These programs had a positive effect on development of HRM policies and procedures in organisations incorporating diversity management concept (Konrad and Linnehan, 1995; Holzer and Neumark, 2000). In addition, research has shown these programs contributed to employing more women and members of other social groups. In the context of Canadian organisations who, incorporating broad equal opportunities programs, hired more women than others, especially women with disabilities and women form minority ethnical groups (Leck and Saunders, 1992). In the context of USA, the research has shown that organisations, aware of possible legal procedures based on failing to implement the obligations from equal opportunity programs, have more women in leadership positions and employ more persons from minority social groups compared to organisations who are not aware of possible repercussions (Konrad and Linnehan, 1995). In addition, organisations with positive attitude towards equal opportunity programs tend to develop gender specific strategies through mentorship and networking in order to overcome prejudice against (French, 2001). 


\section{Career development}

Proper training and career development have a very positive effect on women career development, as confirmed by numerous researches. Research in a large multinational company specialised in financial services point that personal growth possibilities represent an important condition in career development of women and men (Lyness and Judiesch, 1999). Training and personal growth possibilities are directly related to advancement of women to management positions (Metz and Tharenou, 2001).

Mentorship as an important factor in professional and managerial development has an especially positive influence on career success of women (Lyness and Thompson, 2000; Tharenou, 2005), but women also have more obstacles in gaining benefits from mentoring compared to men (Ragins and Cotton, 1991). Ragins and Cotton (1999) established that women, compared to men, gain less benefit in career development from learning and communicating with a formal mentor than informal mentorship.

Access to professional networks as source of knowledge and information is very important for career development (Brown and Konrad, 2001a, 2001b). Research on internal and external professional networks of women and men in management in large organizations revealed the segregation among them and the fact women have less access to managers in higher positions mostly made of men (Burke et al., 1995). In support of this research Linehan (2001) established that women managers in Europe consider lack of possibilities to network with senior management in organisation a significant disadvantage in career development.

\section{Formalisation of HRM system}

Formalising the decision making process about employees has positive effects on career development of women in organisations. In addition, Reskin and Branch McBrier (2000) indicated, if organisations use formalised recruitment methods, especially in vacancy advertisement, and if they use recruitment agencies they are likely to have more women in management positions. The level of formalisation in the compensation process has positive effects on equal salaries for women (Elvira and Graham, 2002). However, the research in medical care indicated that informal compensation process, when combined with greater dispersion of salaries, resulted in lower salaries for women doctors (Konrad et al., 2012). To summarise, research indicate that formalisation in HRM decision making process has a positive effect on professional development of women in organisations.

\section{Balancing between the professional and private life}

Based on numerous research we can safely say that $2 / 3$ of women in the world, and possibly more, take care of family members and perform household jobs (Geist, 2005; Lee and Waite, 2005; Li, 2005) making work - private life balance very important to professional development of women. Forming a family has a strong influence on women career development, with varying effect in different societies. In USA marriage does not influence the number of women employed but the arrival of children does influence the number of hours women are paid for (Cohen and Bianchi, 1999), while in China, marriage and children have little influence on the composition of woman in the work force (Yi and Chien, 2002). Trying to balance professional development with family obligations women are looking for options to improve the work - private life balance. Organisations are trying to adapt to the changes with different policies, especially with young employees who are trying to maintain balance between work and other aspects of life (Wey Smola and Sutton, 2002).

Research shows that benefits from work - life balance has positive effects on women, but also other employees. Holtzman and Glass (1999) indicated that longer maternity leave, flexible working hours and the possibility to work at home have a positive relation with job satisfaction. Dreher (2003) also indicated that benefits from work private life balance in 1994 had a positive relation with number of women in senior management positions in 1999.

Summarising, benefits from work - private life balance have positive effects on job satisfaction among women but also other employees and can benefit organisations with reduced workforce drain.

\section{CONCLUSION}

Numerous researches indicate that the said HRM policies and procedures have positive effects on professional development of women and their career advancement. The positive effect of HRM policies and procedures is reflected in the process of recruitment, selection, training, development, career advancement and retention of employees. Analysing 
four types of HRM policies and procedures presented in the paper indicate that each of them have positive influence on professional development of women and their career advancement, especially in the aspect of mentoring, professional networking, formalisation of HRM system and work - private life balance.

To summarise, it is important to point out the potential for further research. Researches so far were not able to explain how the application of HRM policies and procedures based on diversity management connect with the business strategy of the organisation. Having that in mind, HRM should have a strategic approach to creation, implementation and evaluation of the said policies and procedures.

Specifically in relation to HRM and professional development and promotion of women in organisations the researcher so far has mainly focused on white women, representing majority of women. Future research should include the problems relating to women from different ethical groups and women with disabilities in their analysis, implicating that HRM practice should be adjusted to women from different social groups (Proudford, 1999). The HRM practice aimed in removing obstacles in career development of white women should be adjusted to include women from different ethnic groups (Bell and Nkomo, 2001).

Important aspect in research relates to the age differences among women. Negative stereotypes about older women have negative effect on both man and women (Perry and Parlamis, 2006), indicating that those stereotypes are more prominent in older women than older men (McKelvie, 1993). We can conclude that outcomes in professional development are gender sensible and future research should take that into account. Another important aspect is treatment of persons with disabilities at work, especially women. Research in Canada indicated that women with disabilities faced additional humiliation at work due to their disability (Carr et al., 2003). Additional research is necessary to explore the efficiency of HRM practice towards employees with disabilities, especially women.

\section{REFERENCES}

Recruiting staff: guidance for managers and supervisors. (2004). from Equal Opportunities Commission (UK) www.eoc.org.uk

Bell, E. E., \& Nkomo, S. M. (2001). Our Separate Ways: Black and White Women and the Struggle for Professional Identity. Boston, MA: Harvard Business School Press.
Brown, D. W., \& Konrad, A. M. (2001a). Granovetter Was Right: The Importance of Weak Ties to a Contemporary Job Search. Group \& Organization Management, 26(4), 434-462. doi: $10.1177 / 1059601101264003$

Brown, D. W., \& Konrad, A. M. (2001b). Job-Seeking in a Turbulent Economy: Social Networks and the Importance of Cross-Industry Ties to an Industry Change. Human Relations, 54(8), 1015-1044. doi: 10.1177/0018726701548002

Burke, R. J., Rothstein, M. G., \& Bristor, J. M. (1995). Interpersonal networks of managerial and professional women and men: descriptive characteristics. Women In Management Review, 10(1), 21 - 27.

Carr, J., Huntley, A., MacQuarrie, B., \& Welsh, S. (2003). Workplace Harassment and Violence (Report ed.): Status of Women Canada.

Cohen, P. N., \& Bianchi, S. M. (1999). Marriage, children, and women's employment: what do we know? Monthly Labor Review, 122(12), 22-31.

Davidson Perlmutter, F., Deckop, J. R., Konrad, A. M., \& Freely, J. L. (2005). Nonprofits and the Job Retention of Former Welfare Clients. Nonprofit and Voluntary Sector Quarterly, 34(4), 473-490. doi: $10.1177 / 0899764005278034$

Dreher, G. F. (2003). Breaking the glass ceiling: the effects of sex ratios and work-life programs on female leadership at the top. Human Relations, 56(5), 541562 doi: 10.1177/0018726703056005002

Elvira, M. M., \& Graham, M. E. (2002). Not Just a Formality: Pay System Formalization and Sex-Related Earnings Effects. Organization Science, 13(6), 601617. doi: 10.1287/orsc.13.6.601.499

Fine, M. G. (1995). Building Successful Multicultural Organizations: Challenges and Opportunities. Westport, CT: Greenwood.

French, E. L. (2001). Approaches to equity management and their relationship to women in management. British Journal of Management, 12(4), 267-285.

Geist, C. (2005). The Welfare State and the Home: Regime Differences in the Domestic Division of Labour. European Sociological Review, 21(1), 23-41. doi: 10.1093/esr/jci002

Heneman, R. L., Waldeck, N.E., \& Cushnie, M. (1996). Diversity considerations in staffing decision-making. In E. E. Kossek \& S. A. Lobel (Eds.), Managing Diversity: Human Resource Strategies for Transfoming the Workplace (pp. 74-102). New York: Blackwell.

Holtzman, M., \& Glass, J. (1999). Explaining Changes in Mothers' Job Satisfaction Following Childbirth. Work and Occupations: An International Sociological Journal, 6(3), 365-404.

Holzer, H. J., \& Neumark, D. (2000). What Does Affirmative Action Do? Industrial and Labor Relations Review, 53(2), 240-271.

Johnston, W. B. (1987). Workforce 2000: Work and Workers for the Twenty-First Century. Indianapolis, Indiana: Hudson Institute, Herman Kahn Center.

Konrad, A. M., \& Deckop, J. (2001). Human resource management trends in the USA - Challenges in the midst of prosperity. International Journal of 
Manpower, 22(3), 269 - 278. doi: $10.1108 / 01437720110398374$

Konrad, A. M., \& Linnehan, F. (1995). Formalized HRM Structures: Coordinating Equal Employment Opportunity or Concealing Organizational Practices? The Academy of Management Journal, 38(3), 787820.

Konrad, A. M., Yang, Y., \& Cannings, K. (2012). Pay dispersion and earnings for women and men: a study of Swedish doctors. Gender in Management: An International Journal, 27(4), 249 - 270. doi: $10.1108 / 17542411211244795$

Leck, J. D. (2002). Making Employment Equity Programs Work for Women. Canadian Public Policy/Analyse de Politiques, 28(Supplement: Occupational Gender Segregation: Public Policies and Economic Forces), S85-S100.

Leck, J. D., Onge, S. S., \& Lalancette, I. (1995). Wage Gap Changes among Organizations Subject to the Employment Equity Act. Canadian Public Policy / Analyse de Politiques, 21(4), 387-400.

Leck, J. D., \& Saunders, D. M. (1992). Hiring Women: The Effects of Canada's Employment Equity Act. Canadian Public Policy / Analyse de Politiques, 18(2), 203-220.

Lee, Y.-S., \& Waite, L. J. (2005). Husbands' and wives' time spent on housework: A comparison of measures. Journal of Marriage and Family, 67(2), 328-336. doi: 10.1111/j.0022-2445.2005.00119.x

Li, J. (2005). Women's Status in a Rural Chinese Setting. Rural Sociology, 70(2), 229-252. doi: $10.1526 / 0036011054776352$

Linehan, M. (2001). Networking for female managers' career development: Empirical evidence. Journal of Management Development, 20(10), 823 - 829.

Lyness, K. S., \& Judiesch, M. K. (1999). Are Women More Likely to Be Hired or Promoted into Management Positions? Journal of Vocational Behavior, 54(1), 158-173.

Lyness, K. S., \& Thompson, D. E. (2000). Climbing the Corporate Ladder: Do Female and Male Executives Follow the Same Route? Journal of Applied Psychology, 85(1), 86-101.

McKelvie, S. J. (1993). Stereotyping in perception of attractiveness, age, and gender in schematic faces. Social Behavior and Personality: an international journal, 21(2), 121-128.

Metz, I., \& Tharenou, P. (2001). Women's career advancement: the relative contribution of human and social capital. Group Organization Management, 26(3), 312-342. doi: 10.1177/1059601101263005

Perkins, L. A., Thomas, K. M., \& Taylor, G. A. (2000). Advertising and recruitment: Marketing to minorities. Psychology \& Marketing, 17(3), 235-255.

Perry, E. L., \& Parlamis, J. D. (2006). Age and Ageism in Organizations: A Review and Consideration of National Culture. In A. M. Konrad, P. Prasad \& J. K. Pringle (Eds.), Handbook of Workplace Diversity (pp. 345-370). London, UK, Thousand Oaks, CA: Sage.

Proudford, K. L. (1999). The Dynamics of Stigmatizing Difference. Journal of Career Development, 26(1), 7 20. doi: 10.1177/089484539902600102

Ragins, B. R., \& Cotton, J. L. (1991). Easier Said than Done: Gender Differences in Perceived Barriers to Gaining a Mentor. The Academy of Management Journal, 34(4), 939-951.

Ragins, B. R., \& Cotton, J. L. (1999). Mentor functions and outcomes: a comparison of men and women in formal and informal mentoring relationships. Journal of Applied Psychology, 84(4), 529-550.

Reskin, B. F., \& Branch McBrier, D. (2000). Why Not Ascription? Organizations' Employment of Male and Female Managers. American Sociological Review, 65(2), 210-233.

Tharenou, P. (2005). Does Mentor Support Increase Women's Career Advancement More than Men's? The Differential Effects of Career and Psychosocial Support. Australian Journal of Management, 30(1), 77-109. doi: 10.1177/031289620503000105

Vinnicombe, S., \& Singh, V. (2003). Women-only management training: An essential part of women's leadership development. Journal of Change Management, 3(4), 294-306.

Wey Smola, K., \& Sutton, C. D. (2002). Generational differences: revisiting generational work values for the new millennium. Journal of Organizational Behavior, 23(4), 363-382. doi: 10.1002/job.147

Yi, C.-C., \& Chien, W.-Y. (2002). The Linkage Between Work and Family: Female's Employment Patterns in Three Chinese Societies. Journal of Comparative Family Studies, 33(3), 451-474. 